\title{
Software Testing using the Black Box Method: Case study - Pioneer Tourism Web in Southeast Minahasa
}

\author{
Olga E. Melo \\ Dept. of Information Technology \\ State polytechnic of Manado \\ Indonesia
}

\author{
Oktavianus Lintong \\ Dept. of Tourism \\ State polytechnic of Manado, \\ Indonesia
}

\author{
Harson Kapoh \\ Dept. of Information Technology \\ State polytechnic of Manado \\ Indonesia
}

\author{
Ivonne Putong \\ Dept. of Accounting \\ State polytechnic of Manado, \\ Indonesia
}

\author{
Anthon A. Kimbal \\ Dept. of Information Technology \\ State polytechnic of Manado \\ Indonesia
}

\begin{abstract}
Southeast Minahasa Regency which is part of North Sulawesi Province also has many tourism objects including well-known natural attractions.

In this study ours conducted a study on the quality of existing pilot tourism web using the Black Box method. The pilot tourism web is made specifically for tourist objects that are not too well known or not yet known by the wider community but are only known by the local community or around. The purpose of this website is as a place to promote pilot tourism objects in Southeast Minahasa Regency. So that it can become an alternative tourist destination that can be visited by the wider community both in the province of North Sulawesi, National, and International.
\end{abstract}

Black Box testing will be carried out to test the quality of this pilot travel web software without paying attention to the code and program structure, which means that only pay attention to whether the output is as expected or not.

The purpose of this study is to determine whether the software is in accordance with the expected software specifications.

Tests that have been carried out using the Black Box method cannot be separated from the desire to find out the errors that exist in the pilot tourism web software. In this test, the software being tested shows that the implementation of the software has been correctly carried out through functions according to the software specification requirements.

\section{General Terms}

Software Testing

\section{Keywords}

Testing, Black Box, Web Tourism

\section{INTRODUCTION}

North Sulawesi Province is a province located in the North of Sulawesi Island which has many tourist attractions. Currently a famous tourist attraction to foreign countries is the Bunaken National Park which is an underwater park located on Bunaken Island.

The beauty of the Bunaken marine park has been well recognized in foreign countries apart from its beauty as well because promotions through various media are available including those on google facilities.

Southeast Minahasa Regency which is part of North Sulawesi Province also has many tourism objects including well-known natural attractions.

In this study we conducted a study on the quality of existing pilot tourism web using the Black Box method. The pilot tourism web is made specifically for tourist objects that are not too well known or not yet known by the wider community but are only known by the local community or around. The purpose of this website is as a place to promote pilot tourism objects in Southeast Minahasa Regency. So that it can become an alternative tourist destination that can be visited by the wider community both in the province of North Sulawesi, National, and International.

Black Box testing will be carried out to test the quality of this pilot travel web software without paying attention to the code and program structure, which means that only pay attention to whether the output is as expected or not.

The purpose of this study is to determine whether the software is in accordance with the expected software specifications.

\section{RELATED RESEARCH}

Some related research

Research by Bansal (2014), this study uses comparisons between blackbox testing with 2 other methods, namely the whitebox testing method and greybox testing. The results of this study indicate that the blacbox testing method does not look at the internal structure, in contrast to the whitebox testing which looks at the inner structure as a whole. While using the greybox testing method, only partially the structure is considered [1].

By Supriadi, Bambang in 2014 with the title Alternative Development of Mount Bromo Tourism Stubs. The purpose of this research is to develop tourism pilots that have tourism potential on the Mount Bromo route through the north and south routes of Pasuruan. The analysis method uses statisticaldescriptive analysis to identify the problems stated above, a sample of 50 tourists at the DTW Mount Bromo. In conclusion, there are 5 (five) tourist attractions to be developed. All of the tourism pioneers in the Mount Bromo route have good potential considering the average mean value is 3.7 (good) on the Linkert scale and think very beautiful and beautiful, the mean is 4.1 the tourists have a good opinion and 
there are no bad commentators, all agree that it is beautiful. The tourist attraction of the desert in this tourist spot has a good value of $90 \%$ and very good $10 \%$ and no tourists are disappointed with this tourism potential. Pioneering the tourism attractiveness of the existence of cultural heritage in this tourist spot has a good value of $35 \%$ and a good enough $15 \%$ and only $4 \%$ who still consider it lacking, but the majority of tourists who are disappointed with this tourism potential are not there. Pioneering tourist attraction historical existence in this tourist spot has a very good score of $22 \%$ and quite good $14 \%$ and only $2 \%$ who still consider it insufficient. $\mathrm{Xu}$ et al's research (2016), tested using the blackbox testing method used in open source software. The software being tested are Advance Trigonometry Calculator and Personal Bank Account Manager (YAPBAM). The result of the research is that testing shows that the testing is thorough and relatively accurate which may require all software whenever possible with the application of the available combinations. Certain testing techniques do not guarantee a high level of efficiency because the number of known bugs is also high; in the test analysis it is therefore necessary to estimate the costs that may exist in each application of the test technique; it appears that most of the defects in software were negative in the test cases performed; error correction is not selalu dilakukan dengan memodifikasi kode sumber[2].

\section{TEORY}

Black-Box Testing is a software testing technique that focuses on the functional specifications of software [3], [4]. Blackbox Testing works by ignoring the control structure so that attention is focused on domain information [4]. Blackbox Testing method is done without looking at and considering the structure of the software [7]. Blackbox Testing allows software developers to create a set of input conditions that will train all the functional requirements of a program [5, [4]. The advantages of using the Blackbox Tetsting method are [6]: (1) Examiners do not need to have knowledge of a particular programming language; (2) Testing is carried out from the user's point of view, this helps to reveal ambiguities or inconsistencies in the specification of requirements; (3) The programmer and the tester both depend on each other. The shortcomings of the Blackbox Testing method are [6]: (1) Test cases are difficult to design without clear specifications; (2) The possibility of having a repeat of a test that the programmer has already performed; (3) Some parts of the back end are not tested at all.

\section{TESTING METHOD}

4.1 Flowchart Testing

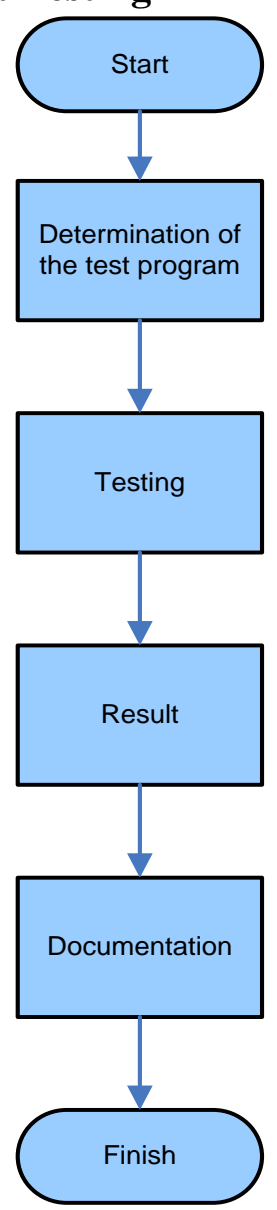

Fig 1: Research Flowchart

Research testing this software uses the following sequence (see Figure 1):

- Determine the program or module to be tested

- Doing testing

- See whether the results are in accordance with expectations

- Documenting test results

\subsection{Some Parts of the Software}

Some parts of the software are presented here as On this web home page, contains several menus that can be used to see startup attractions in Southeast Minahasa (see figure 2)

Login menu is used by user and admin to enter system both front-end and back-end (see figure 3 )

The web also provides users with a map page showing or marking the location of a startup tour (see figure 4)

The web also provides detailed information of the location of the startup attraction by clicking on the location mark on the map on the web (see figure 5) 


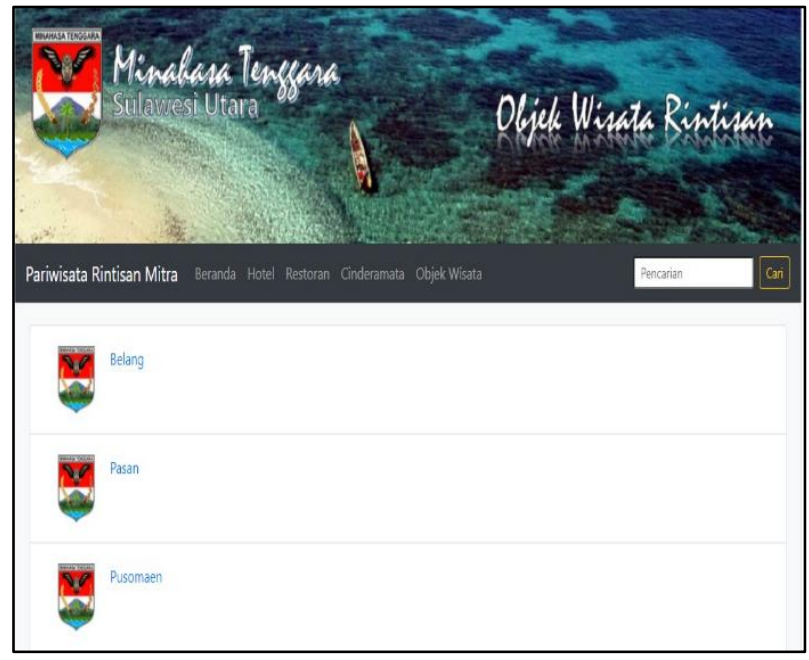

Fig 2: Home Page

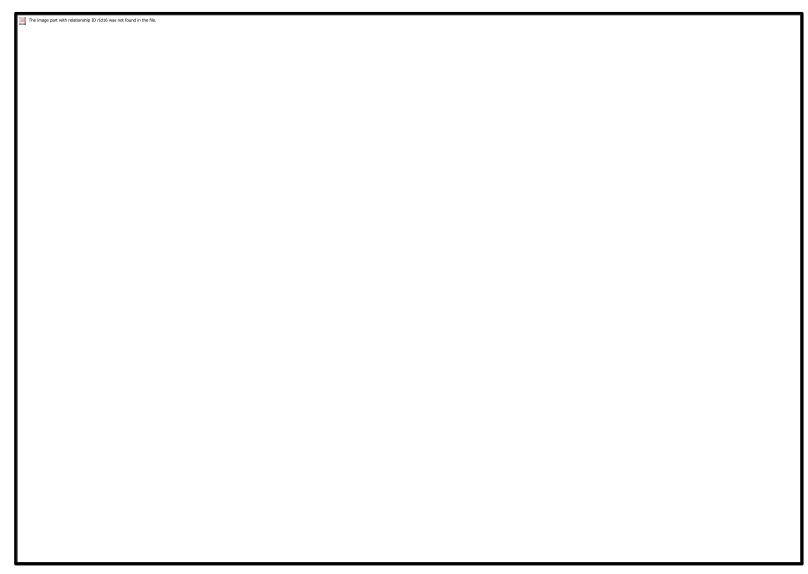

Fig 3: Login Page

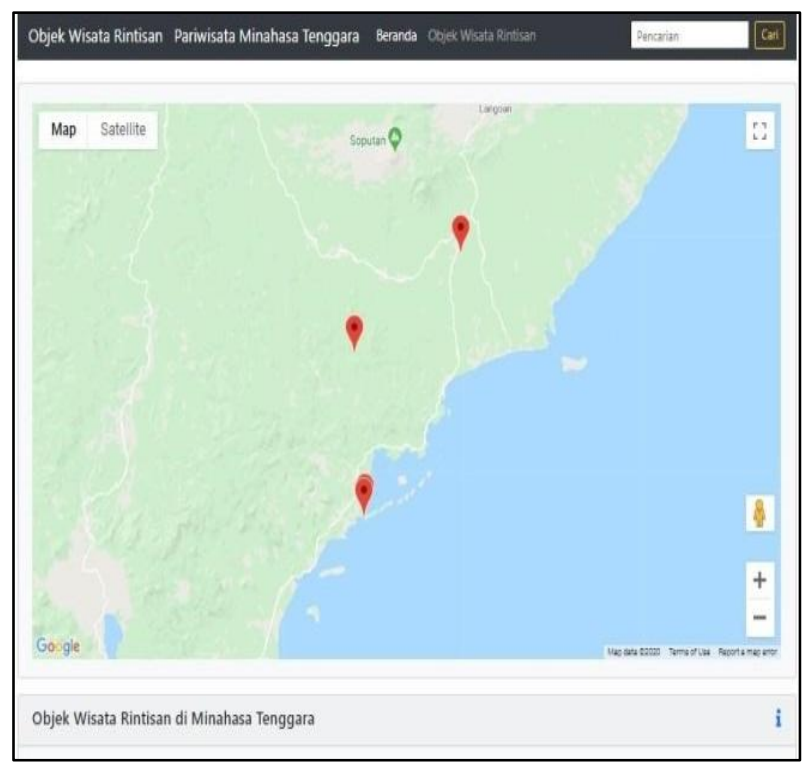

Fig 4: Page of map mark

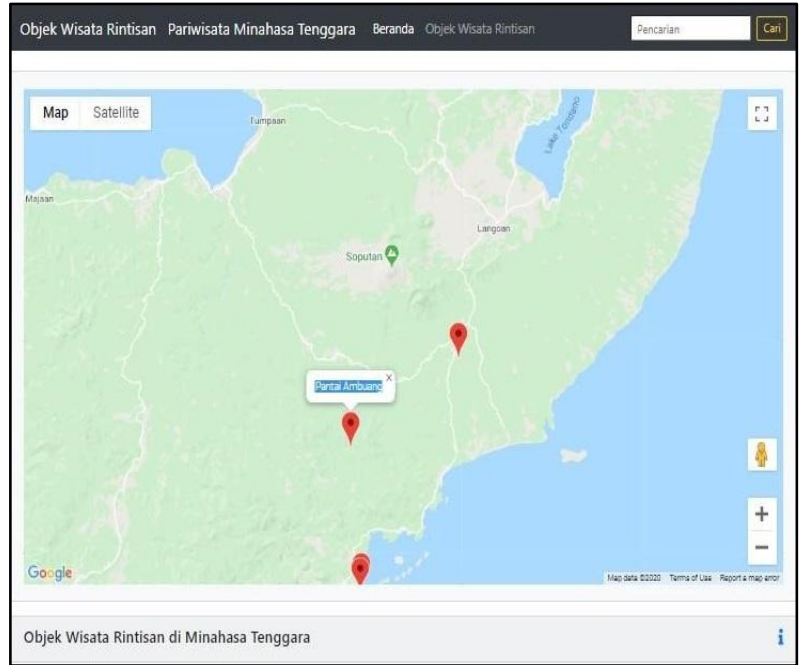

Fig 5: Page of detailed mark information

\section{RESULT AND DISCUSSION}

\subsection{Result}

Table 1. List of Black-Box tests on the front-end system (user)

\begin{tabular}{|c|c|c|c|c|}
\hline No. & Test List & $\begin{array}{c}\text { Test } \\
\text { Scenarios }\end{array}$ & $\begin{array}{c}\text { Expected } \\
\text { Results }\end{array}$ & Actual Result \\
\hline 1. & $\begin{array}{l}\text { Home / } \\
\text { Main page }\end{array}$ & $\begin{array}{l}\text { The user } \\
\text { enters a } \\
\text { name } \\
\text { application } \\
\text { domain on } \\
\text { the web } \\
\text { browser }\end{array}$ & $\begin{array}{l}\text { System } \\
\text { displays } \\
\text { home page } \\
\text { or } \\
\text { main page }\end{array}$ & Corresponding \\
\hline 2. & $\begin{array}{l}\text { Access } \\
\text { detailed } \\
\text { informatio } \\
\text { n } \\
\text { Attractions } \\
\text {, Hotels, } \\
\text { Restaurant } \\
\text { s and } \\
\text { Shops } \\
\text { Souvenirs } \\
\text { via map } \\
\text { spread on } \\
\text { the page } \\
\text { Home }\end{array}$ & $\begin{array}{l}\text { Click the } \\
\text { marker on } \\
\text { the map } \\
\text { the spread } \\
\text { for } \\
\text { bring up } \\
\text { info } \\
\text { window, } \\
\text { then click } \\
\text { "More } \\
\text { Informatio } \\
\text { n" }\end{array}$ & $\begin{array}{l}\text { System } \\
\text { displays } \\
\text { informatio } \\
\text { n detail } \\
\text { page } \\
\text { of the } \\
\text { selected } \\
\text { marker }\end{array}$ & Corresponding \\
\hline 3. & $\begin{array}{l}\text { Display } \\
\text { charts } \\
\text { visitor } \\
\text { monitoring } \\
\text { attractions } \\
\text { per month }\end{array}$ & $\begin{array}{l}\text { Fill in the } \\
\text { month } \\
\text { form fields } \\
\text { and year, } \\
\text { then click } \\
\text { "Show } \\
\text { Graphics" }\end{array}$ & $\begin{array}{l}\text { The system } \\
\text { displays } \\
\text { graphs } \\
\text { visitor } \\
\text { monitoring } \\
\text { tourist } \\
\text { attraction } \\
\text { on the page } \\
\text { pitched }\end{array}$ & Corresponding \\
\hline
\end{tabular}




\begin{tabular}{|c|c|c|c|c|}
\hline No. & Test List & $\begin{array}{c}\text { Test } \\
\text { Scenarios }\end{array}$ & $\begin{array}{c}\text { Expected } \\
\text { Results }\end{array}$ & Actual Result \\
\hline & & & $\begin{array}{l}\text { based on } \\
\text { enter the } \\
\text { month } \\
\text { form and } \\
\text { year }\end{array}$ & \\
\hline 4. & $\begin{array}{l}\text { Object List } \\
\text { page } \\
\text { Travel } \\
\end{array}$ & \begin{tabular}{|l|} 
Click the \\
"Tourism \\
Object" \\
menu \\
on the \\
navigation \\
bar
\end{tabular} & \begin{tabular}{|l|} 
The system \\
displays a \\
list \\
tourist \\
attraction \\
recorded \\
and \\
categorized \\
by \\
recorded \\
districts / \\
cities
\end{tabular} & Corresponding \\
\hline 5. & $\begin{array}{l}\text { Informatio } \\
\text { n Detail } \\
\text { Page } \\
\text { Tourist } \\
\text { attraction }\end{array}$ & $\begin{array}{l}\text { Click an } \\
\text { option } \\
\text { tourist } \\
\text { attraction } \\
\text { on the page } \\
\text { list of } \\
\text { attractions }\end{array}$ & \begin{tabular}{|l|} 
System \\
displays \\
informatio \\
n detail \\
page \\
tourist \\
attraction \\
selected
\end{tabular} & Corresponding \\
\hline 6. & $\begin{array}{l}\text { Get a } \\
\text { travel } \\
\text { route } \\
\text { to the } \\
\text { location of } \\
\text { the tourist } \\
\text { object }\end{array}$ & $\begin{array}{l}\text { Click the } \\
\text { button } \\
\text { "Get it } \\
\text { Travel } \\
\text { route", } \\
\text { then fill in } \\
\text { the } \\
\text { location } \\
\text { the origin } \\
\text { of the user } \\
\text { on the } \\
\text { form and } \\
\text { click "Get } \\
\text { Route" }\end{array}$ & $\begin{array}{l}\text { The system } \\
\text { displays a } \\
\text { map } \\
\text { and } \\
\text { directions } \\
\text { informatio } \\
\text { n } \\
\text { to the } \\
\text { location of } \\
\text { a tourist } \\
\text { attraction }\end{array}$ & Corresponding \\
\hline 7. & $\begin{array}{l}\text { Leave a } \\
\text { review } \\
\text { tourist } \\
\text { attraction } \\
\text { visitors }\end{array}$ & \begin{tabular}{|l|} 
Click the \\
button \\
"Give \\
Reviews \\
About \\
Objects \\
Tour", \\
then \\
fill in the \\
fields for \\
the review \\
\end{tabular} & $\begin{array}{l}\text { Successfull } \\
\text { y saved } \\
\text { data } \\
\text { reviews on } \\
\text { the } \\
\text { database. }\end{array}$ & Corresponding \\
\hline
\end{tabular}

\begin{tabular}{|c|c|c|c|c|}
\hline \multirow[t]{2}{*}{ No. } & Test List & $\begin{array}{c}\text { Test } \\
\text { Scenarios }\end{array}$ & $\begin{array}{l}\text { Expected } \\
\text { Results }\end{array}$ & Actual Result \\
\hline & & $\begin{array}{l}\text { form } \\
\text { and click } \\
\text { "Submit" }\end{array}$ & & \\
\hline 8. & $\begin{array}{l}\text { List hotel } \\
\text { Page }\end{array}$ & $\begin{array}{l}\text { Click the } \\
\text { "Hotel" } \\
\text { menu } \\
\text { navigation } \\
\text { bar }\end{array}$ & $\begin{array}{l}\text { The system } \\
\text { displays a } \\
\text { list } \\
\text { hotel } \\
\text { recorded. }\end{array}$ & Corresponding \\
\hline
\end{tabular}

The test chosen is a front-end system on the user's side with the final results of the testing being all in accordance with the expectations, namely in accordance with the needs of the software specifications. Therefore, in testing with the Black Box method, it only looks at whether the input, process and output can be run without any errors and produce output or information as expected.

\subsection{DISCUSSION}

Tests that have been done show that the software functions work in accordance with the device specifications and this is good because it shows that the performance requirements have been met.

In the testing process the principle of testing is used to uncover errors. So that later the software being tested is deemed unable to meet its requirements if some or all errors are found.

Based on the above principles, the test carried out to find errors is to enter data in accordance with the required process or in accordance with the scenario. The data entry in this test is alphanumeric data and the response from the trigger software is given by clicking on the mouse.

In order for testing to be carried out efficiently, this test is carried out every time a function of the software has been developed so that you can see the errors in the program.

What is usually done if an error is found in the software. But according to $\mathrm{Xu}$ et al, if there is an error in the software and you want to correct the error, it will not always be by modifying the program code [1]. That happens because the tests carried out do not pay much attention to the program code but more to the functions that exist in the software.

\section{CONCLUSION}

Tests that have been carried out using the Black Box method cannot be separated from the desire to find out the errors that exist in the pilot tourism web software. In this test, the software being tested shows that the implementation of the software has been correctly carried out through functions according to the software specification requirements. In the future, testing can be done to determine the efficiency of software engineering by conducting several related studies such as the White box method.

\section{ACKNOWLEDGMENTS}

Our thanks to Manado State Polytechnic for giving the opportunity to conduct this research.

\section{REFERENCES}

[1] S. Xu, L. Chen, C. Wang, and O. Rud., 2016. A comparative study on black-box testing with open source 
applications. 2016 IEEE/ACIS 17th Int. Conf. Softw. Eng. Artif. Intell. Netw. Parallel/Distributed Comput. SNPD 2016, pp. 527-532.Bowman, M., Debray, S. K., and Peterson, L. L. 1993. Reasoning about naming systems.

[2] A. Bansal., 2014. A Comparative Study of Software Testing Techniques. Int. J. Comput. Sci. Mob. Comput., vol. 36, no. 6, pp. 579-584,

[3] S. Roohullah Jan, S. Tauhid Ullah Shah, Z. Ullah Johar, Y. Shah, and F. Khan., 2016. An Innovative Approach to Investigate Various Software Testing Techniques and Strategies. Int. J. Sci. Res. Sci. Eng. Technol., vol. 2, no. 2, pp. 682-689.

[4] J. Watkins., 2001. Testing IT An Off The Shelf Software

\section{Testing Process.}

[5] A. Bansal., 2014. A Comparative Study of Software Testing Techniques. Int. J. Comput. Sci. Mob. Comput., vol. 36 , no. 6 , pp. $579-584$,

[6] P. Ammann, J. Offutt, and I. Version., 2016. Introduction to Software Testing Edition 2 Paul Ammann and Jeff Offutt Instructor Version. pp. 2002-2009.

[7] K. Harson, L. Edwin. and Nikita A.E.S "Design model material requirement of coconut flour production and performance testing based multi user in North Sulawesi”,IEEE xplorer, pp. 1-7, 2016[Knowledge Creation and Intelligent Computing (KCIC), International Conference on] 